\title{
Anne Brontë: The Triumph of Realism over Subjectivity
}

\author{
Breatriz Villacañas Palomo \\ University of Madrid, Complutense
}

\begin{abstract}
The name of the Brontës has been traditionally associated with romantic fiction. However, neither the themes nor the characters of the third Brontë are the products of a romantic imagination. She shared with her sisters the same self absorbed family world and dramatic circumstances, but, unlike them, she does not project autobiography to the realm of passion and symbolism. Instead, as is plain to be seen in her two novels, Anne Brontë masters her own subjectivity and shapes it with an objective presentation of people and maners which enables her to make a radical indictment of some unjust realities of her own time.
\end{abstract}

\section{Diverging ways}

In most references, lessons, or criticism about the Brontës, Anne occupies, if any, a rather reduced place beside her elder sisters. Some have even affirmed that she enjoys her position thanks to the prestige of the egregious Charlotte and Emily (Mackay). However, a close survey of her two novels may lead us to an opposite conclusion, namely, that the literary figure of Anne Brontë has been usually slighted because of the literary fame of the authoresses of Jane Eyre and Wuthering Heights.

It is indeed difficult to hold one's own when flanked by two giants, and perhaps critics have been inclined to consider that two acknowledged geniuses in just one family is more than enough as far as literary assessment goes. However, whether Anne's achievement can compare to that of her sisters is not really the question here, because hers belongs to a surprisingly different kind, comparable to Charlotte's The Professor, Shirley and Villette, in its quest for the realistic, unromantic truth, but precisely because of this quest, opposite to the two novels by Charlotte and Emily (Jane Eyre and Wuthering Heights respectively), which gave their creators unquenchable literary fame.

We are accustomed to relating the Brontës with romantic fiction, due to the passion and intensity of imagination that permeates the most renowned works of the elder sisters. 
It is precisely in this association where the name of the third Brontë does not seem to fit at all. Neither her themes nor her characters are the products of a romantic imagination. It is important, thus, for us to realize that apart from some common elements of a gothic and imaginative kind in the three sisters, Anne Brontë's art is basically a realistic one. And yet, Anne's realism springs from the same roots which nourish the so-called romanticism of her elder sisters. In the first place, the three of them show themselves to be thoroughly honest and loyal to truth in their works. As Charlotte declares:

The first duty of an author is, I conceive, a faithfal allegiance to Truth and Nature ... The Bells are very sincere in their worship of Truth, and they hope to apply themselves to the consideration of Art, so as to attain one day the power of speaking the language of conviction in the accents of persuasion; though they rather apprehend that whatever pains they take to modify and soften, an abrupt word or vehement tone will now and then occur to startle ears polite, whenever the subject shall chance to be such as moves their spirits within them.'

This brave adherence to the principle of honesty, shared by the three Brontë sisters, would cause the well-known accusations of "coarseness," and "brutality" which the three had to share as well. Secondly, it is always necessary to refer to their family background whenever we set out to analize the works of the Brontës. The isolation of their motherless childhood in the rectory of Haworth with an aunt and a widowed father, the surrounding wilderness and loneliness of the moorlands. Their sibbling games and writings which created the passionate dream-worlds of Angria and Gondal, the deaths of the two eldest sisters, Maria and Elizabeth, in childhood, the personal ruin and premature death of the only son and brother of the family. The story of their lives impresses us like a powerfully tragic novel, which if written in the novel form, would be too intensely romantic to be convincing.

It is certainly not difficult to realise the influence of this self-absorbed family world on the imagination of the Brontë sisters, of which we have the best proof in Jane Eyre and Wuthering Heights. But then, what about Anne? Together with the characteristic devotion to truth, she also shared the same background and some crucial experiences with her sisters, and yet, when it came to writing, she let aside the tempestuous subjectivity of Charlotte and the overwhelming passion of Emily. In Agnes Grey, her first novel, Anne draws from the invaluable sources of her own unhappy life as a governess, but unlike what Charlotte does in the likewise autobiographical Jane Eyre, she does not project autobiography to the realm of passion and symbolism, but makes it a solid standpoint for observation of people and manners. Agnes Grey is a "realistic" portrait of moneyed English families in the early nineteenth century-pretentious, snobbish, and vain-and of their cruel and pampered children. While Mr. Rochester is the creation of the fantasy of a passionate woman, those characters like the nuveaux-riches Bloomfields and the more aristocratic Murrays, or Uncle Robson, are easily recognizable in the real context of their own time.

The main characters who populate Wuthering Heights belong to another realm of existence. They have a powerful reality, but their reality is not to be found in terms of 
realistic portrayal. Theirs is the world of Angria and Gondal, where passion overflows all limits, in which creation and destruction, love and death, feed mutually each other. The characters of Anne Brontë's novels, on the contrary, have, even in the extreme case of Arthur Huntingdon, their equivalent in the real world. And this is so because she relied not so much on imagination as on observation, for which, one may say, she was both temperamentally suited and also circumstantially situated, since, as a governess, she was very much in a position to observe the ways of those families with which she stayed, and which made it clear from the start that she was a social inferior to them.

The loneliness Anne suffered, the pangs of constantly injured self-esteem, never obtrude in her firm aim of faithfulness to truth in its most realistic manifestation. We cannot be too thankful to her for the precious information she offers us in Agnes Grey of the unenviable position of the English governess, and of the economically and socially powerful classes who employed her. And this is so because Anne Brontë exposes what she had observed adhering to her belief, stated at the opening of Agnes Grey, that "all true histories contain instruction." Thus, her novels become a revelation.

Curiously enough, according to its authoress, Agnes Grey, "was accused of extravagant over-colouring in those very parts that were carefully copied from the life, with a most scrupulous avoidance of exaggeration. ..."2 As so often happens, reality can be the most difficult thing to believe. George Moore (222), the critic, might have had in mind Anne's combination of unpretentiousness and accuracy when assessing Agnes Grey: "It is more difficult to write a simple story than a complicated one," aadding that

... nothing short of genius could have set (the details) before us so plainly and yet with restraint ... it is the one story in English literature in which style, character and subject are in perfect keeping.

Moore compares Anne's writing to that of Jane Austen, which no doubt is indicative of the former's concentration upon human beings in their relationships, reactions, and concrete place in society. It is also interesting to quote F. B. Pinion's (237-38) words in this respect:

In Agnes Grey her main aim is to expose society through its exploitation of the governess. Had Dickens been able to present the subject, he would have given more sensational and colourful scenes, with caricature and satire, but nothing more faithful and convincing.

We can witness scenes as vivid as when the unexperienced and sensitive Agnes tries, to no avail, to inculcate some compassion on the seven-year old Tom Bloomfield, whose cruelty to birds and animals is either overlooked or encouraged by the members of his family. After his uncle has given him a nestful of young birds he relishes at the perspective of torturing them, and the powerless governess is forced to drop a flat stone on the helpless creatures so as to avoid their torments. The uncle, Mr. Robson, after abusing Agnes for her action, delights in his nephews furious tantrum, which he considers proper manliness:

Damme, but the lad has some spunk in him, too. Curse me if I ever saw a nobler little scoundrel than that. He's beyond petticoat government already: by God! he defies 
mother, granny, governess and all! Ha, ha ha! Never mind, Tom, I'll get you another brood tomorrow. (648-49)

Following this same incident, Mrs Bloomfield, Tom's mother, betrays with her own words her lack of any spiritual refinement:

"I am sorry, Miss Grey, you should think it necessary to interfere with Master Bloomfield's amusements; he was very much distressed about your destroying the birds... You seemed to have forgotten that the creatures were all created for our convenience."

I thought that doctrine admitted some doubt, but merely replied: "If they were, we have no right to torment them for our amusement."

"I think," she said, " a child's amusement is scarcely to be weighed against the welfare of a souless brute." (649)

The writer's insight is manifest in the portrayal of the different human types who populate the world of Agnes Grey. Anne Brontë is a veritable master in making her characters expose themselves in their own words and apparently insignificant details of their behaviour. It is here where the genius of realism shows. With an instinct for economy and precision she presents us the figure of rigid and class-conscious priesthood in the rector Mr. Hatfield. Young and vain, Mr. Hatfield is indifferent and impatient with the poor cottagers of his parish. To Agnes he never addressed one single word, not being more than a governess in his eyes, but his ingratiating ways with her employers, the Murrays, do not pass unnoticed by Agnes:

... I thought it somewhat derogatory to his dignity as a clergyman to come plying from the pulpit to shake hands with the squire and hand his wife and daughters into the carriage.... (671)

The Rector's high social aspirations lead him to court the pretty Rosalie Murray, the squire's elder daughter. In one of his walks with her, Snap, the dog which had come under Agnes's care, ran towards the object of his courtship:

But Snap, running before me, interrupted her in the midst of some half-pert, half-playful repartee, by catching hold of her dress and vehemently tugging thereat; till Mr. Hatfield, with his cane, administered a resounding thwack upon the animal's skull, and sent it yelping back to me, with a clamorous outcry that afforded the reverend gentleman great amusement. ... (694)

A genuine Christian, and at the same time a penetrating one, Anne Brontë could never fail to see when others, especially those representing the Church, fell short, in their meanness and egotism, of the logical expectations of their holy position. In cases of this sort, the novelist lets her critical voice be heard. In the chapter on the poor cottagers, Anne Brontë's uncompromising spirit achieves superb critical realism when old Nancy Brown, chatting with Agnes, tells her in her own naïve but perspicacious way about Mr. Weston, 
the Rector's new curate, and makes clear the difference between the two ecclesiastical men:

... and when the cat, poor thing jumped on to his knee, he only stroked her and gave a bit of a smile: so I thought that was a good sign; for once, when she did so to th' rector, he knocked her off, like as it might be in scorn and anger, poor thing. But you can't expect a cat to know manners like a Christian, you know, Miss Grey. (680)

Agnes Grey, unlike its authoress's own life, and most probably unlike the lives of most governesses, has a happy ending. But this does not diminish the scrupulous accuracy of the story it tells. The reading public expected happy endings in the novels, and publishers favoured them, although this does not necessarily mean Anne Brontë felt obliged to contrive a happy ending for her novel. She was probably fulfilling in her writing the most legitimate human aspiration of happiness, especially happiness after trial. Improbable as it might have been in real life, we must not consider Agnes's marriage to Mr. Weston mere wishful thinking, but part of the moral teaching of a true story, and which presents, nonetheless, a vision of married life which excludes any romantic or idealistic notions. Agnes Grey's words at the end of her diary echo the moderate expectations of a woman who, like Anne Brontë herself, instead of dreaming, has come to terms with the reality of human life:

... I became the wife of Edward Weston; and never have found cause to repent it, and am certain, I never shall. We have had trials, and we know that we must have them again; but we bear them well together, and endeavour to fortify ourselves and each other against the final separation-that greatest of all afflictions to the survivor. $(748-49)$

Anne Brontë's second novel, The Tenant of Wildfell Hall, is partly based on the writer's observations of her second employer family, the Robinsons of Thorp Green, who had also provided ample human material for a great part of Agnes Grey as well. With the Robinsons Anne stayed over a period of four years, and in their house she had "some very unpleasant and undreamt of experiences of human nature." 3 The physical and mental deterioration of Branwell Brontë, a calvary to his family, lies also at the foundations of the novel. But Anne did not allow her subjectivity and personal anguish to impose themselves on her literary task. Instead, as she had done in Agnes Grey, she mastered her own suffering and shaped it with objective, although painful, descriptions of people and situations. And it was so because the youngest Brontë always wrote with the aim of moral instruction in mind and believed in the didactic potentiality of simple and naked truth, its implicit teaching alien to any kind of sermonizing. In the preface to the second edition of the novel Anne Brontë makes clear what her purpose is:

My object in writing the following pages was not simply to amuse the Reader, neither was it to gratify my own taste, nor yet to ingratiate myself with the Press and the Public: I wished to tell the truth, for truth always conveys its own moral to those who are able to receive it. ${ }^{5}$ 
But a fundamental question to understand the full implication of Anne Brontë's work is that the moral of her faithful depiction of reality was, for her time, of a non-conformist and even revolutionary kind.

\section{Indictment and Feminism}

These two terms may, at first sight, appear somewhat shocking when associated with a young woman as unassuming and gentle as Anne Brontë. And yet, it is precisely indictment and feminism what characterise The Tenant of Wildfell Hall. The theme of the novel is the disastrous marriage of a clever and principled woman, Helen, to Arthur Huntingdon, a drunkard and womaniser whose moral standard is literally zero. Helen's husband is a dramatic example of the over-indulgent upbringing of sons, who, unlike daughters, who were guarded and sheltered as if they were the most fragile beings in the world, were allowed, and even encouraged, in those pleasures which English society considered normal and even proper for members of the masculine sex. As Helen herself realizes, "boys were to prove all things by their own experience, while our daughters must not even profit by the experience of others. .." (57).

This double standard for education was seen by Anne Brontë not only as discriminatory, but as extremely dangerous for sons, and so much so since she had firsthand knowledge of her brother Branwell's drinking bouts, drug-addiction and personal ruin. And, with her characteristic fidelity to facts, even those of the most unpleasant kind, she depicts the personal and marital disaster of an unprincipled man, never trained in the slightest form of self-discipline. As Eva Figes (162) points out:

The spoiling of wilful sons, which is such a dominant theme in the social critique presented in women's fiction, is Anne Brontë's central obsession, and she treats the theme with a stark an shocking realism.

The indictment and feminism of this novel lies in Anne's refusal to countenance concealment or disguise of those realities which the Victorians preferred to keep hidden indoors. Considering her situation within the context of her time and as the young daughter of a provincial clergyman, the bravery of the novel and also of the authoresses's words in her preface to the second edition must, perforce, gain our admiration:

... if there were less of this delicate concealment of facts-this whispering "Peace, peace," when there is no peace, there would be less of sin and misery to the young of both sexes who are left to wring their bitter knowledge from experience ... when I feel it my duty to speak an unpalatable truth, with the help of God, I will speak it, though it be to the prejudice of my name and to the detriment of my reader's immediate pleasure as well as my own. ${ }^{6}$

The word "duty" is an essential clue for a just appreciation of Anne Brontë's novels, and very particularly of The Tenant of Wildfell Hall. She herself expresses her hope of doing 
some good, however little, to those capable of receiving the moral of the truth her novel contains, and she considered it her duty to carry out the task of writing about something which at the same time was so very painful for her. Having been called to witness, like her two older sisters, the personal failure and tragedy of someone so very close to her, so loved, and once so promising as her own and only brother, to write about the life and death of Arthur Huntingdon, his progressive decline and the agonies of his last moments must have cost her a superhuman effort. But Anne Brontë proved that despite being gentle and vulnerable she was also valiant and determined. She did not, like Charlotte or Emily had done with Rochester and Heathcliff respectively, endow Huntingdon with any Byronic attributes, she did not choose to make him a fascinating or satanic hero. Instead, she looked at facts in the face and presented us a man whose very human sins made him a wretch, someone to pity, never to be enthralled by.

At this juncture it is necessary to remember that Arthur Huntingdon is not a portrait of Branwell Brontë. Nobody who is somewhat acquainted with the latter's biography would recognise the good-natured, talented and passionate Branwell in the egotistical and shallow Huntingdon. But Branwell was certainly the motive and motif of The Tenant of Wildfell Hall. The deterioration of his life and spirit gave his sisters an aching heart, and to Anne in particular a literary, although unconceivably hurtful, stimulus. She conceived her novel as a warning to others, and might have also felt impelled to write it somehow to expiate her own involuntary responsibility in Branwell's destruction.?

The Tenant of Wildfell Hall is thus an indictment against self-congratulating notions about manhood and about their grave implications and consequences concerning the upbringing of boys and young men. But the authoress made this indictment go beyond this concrete theme and imbued her work with a serene but solid feminism. The real centre of gravitation of the novel is Helen, Arthur Huntingdon's wife, who married him at eighteen, not blind to his already visible shortcomings, but expecting to reform him with an idealism and conviction in keeping with her personality and even more so with her extreme youth. But, after her marriage, Helen soon discovers that her husband has not the virtues that she had supposed hidden behind his flippancy and dissipate habits, and that his faults are of a much more serious kind than she had previously supposed them to be. The progressive disappointment, worries, and final vanishing of all hope about her husband are presented by Anne Brontë to the reader not only with detailed verisimilitude, but with the psychological insight of the writer who is able to understand the working of the human mind and heart, and the effects upon them of external, social, and family factors. One year after her wedding, Helen, who has just become a mother, has already lost her former enthusiasm and come to terms with a less promising reality than she expected. Nevertheless, she still keeps her illusion:

Last Christmas I was a bride, with a heart overflowing with present bliss, and full of ardent hopes for the future-though not unmingled with foreboding fears. Now I am a wife: my bliss is sobered, but not destroyed; my hopes diminished, but not departed; my fears increased, but not yet thoroughly confirmed. . . (253) 
Five years later, Helen has suffered so much neglect, abuse, lies and humiliations from her husband, that the reader, who has witnessed her sufferings, is perfectly prepared to understand the following confession to her own diary:

When they are gone (the guests), how shall I get through the months or years of my future life, in company with that man-my greatest enemy-for none could injure me as he had done? Oh! When I think how fondly, how foolishly I have trusted him, how constantly I have laboured, and studied, and prayed, and struggled for his advantage; and how cruelly he has trampled on my love, betrayed my trust, scorned my prayers and tears, and efforts for his preservation-crushed my hopes, destroyed my youth's best feelings, and doomed me to a life of hopeless misery —as far as man can do it-it is not enough to say that I no longer love my husband-I HATE him! The word stares me in the face like a guilty confession, but it is true: I hate him! (319)

Having read the previous pages of the book, no sensible reader could help sympathising with this woman's indignation. Anne Brontë shows herself to be a master in preparing the ground for her heroine's rebellion so convincingly. It is not only that Arthur Huntingdon is a reckless drunkard, he also contributes for his own amusement to the alcoholism of one of his friends, Lord Lowborough, and has an adulterous relationship with the wife of the latter; incurring in heavy debts, and not having any useful or profitable occupation, squanders Helen's fortune, and spends his time between getting drunk in his London club with his debauched friends, and getting drunk, when they are not hunting, in his own house with those same friends. These latter stay during the whole shooting season under Huntingdon's roof, much to the humiliation of Helen, who has to bear her husband's illtreatment of her in public, the coarse jokes and behaviour of his friends, and has no peace nor respect in her own house.

Being a married woman, Helen had no rights on her own property and fortune, legally under her husband's power. Unjust as the situation was, it was by no means as cruel to Helen as the fact, also according to English law of the time, that it was her own immoral husband who ultimately had the legal power to decide upon her child's future and education. No matter how conscientiously Helen tries to bring up little Arthur, her husband, and in many cases his own thoughtless friends too, demolish all her motherly efferts in a few moments:

My greatest source of uneasiness, in this time of trial, was my son, whom his father and his father's firends delighted to encourage in all the embryo vices a little child can show, and to instruct in all the evil habits he could acquire-in a word to make a man of him' was one of their staple amusements ... So the little fellow came down every evening, in spite of his cross mamma and learnt to tipple wine like papa, to swear like Mr. Hattersley, and to have his own way like a man, and sent mamma to the devil when she tried to prevent him. (357)

By the end of 1824 , according to her diary, and after having discovered the liason of Arthur with Annabella Lawborough under her own roof, Helen was determined to leave her husband. A really revolutionary step for a woman of her time and situation. Being 
completely sure of the righteousness of her decision, she openly makes the proposition to her husband, who refuses it indignantly:

\footnotetext{
"Will you let me take our child and what remains of my fortune and go?"

"Go, where?"

"Anywhere, where he will be safe from your contaminating influence, and I shall be delivered from your presence-and you from mine."

"No-by Jove I won't."

"Will you let me have the child then, without the money?"

"No-nor yourself without the child. Do you think I'm going to make myself the talk of the country, for your fastidious caprices?" (315)
}

No greater criticism against the double legal and moral standards for men and women could have been made with fewer words. Arthur Huntingdon, the unfaithful husband, who has never followed any moral consideration in his behaviour, refuses to let his wife go because of public opinion, particularly that which concerns his own self. And with supreme nonchalance seems to overlook his adultery - for after all, he is a man-and blames his wife of fastidiousness. Two years later, when Helen is determined to abandon him at all costs for the sake of her child, Huntingdon finds out about her projects, destroys her paintings and painting materials by which she had expected to gain a living for herself and her son, and confiscates all her properties:

\footnotetext{
"And meanwhile, I'll trouble you for your keys, my dear." "What keys?"

"The keys of your cabinet, desk, drawers, and whatever else you possess. ..."

"Now then," sneered he, "we must have a confiscation of property."
}

After he had done so, we attend, helpless, to the crushing of the heroine's perspectives:

He then threw my keys into my lap, saying-_"There! you'll find nothing gone but your money, and the jewels-and a few little trifles I thought it advisable to take into my own possession ... I've left you a few sovereigns in your purse, which I expect to last you through the month-at all events, when you want more you will be so good as to give me an account of how that's spent." (370-72)

Anne Brontë makes the reader partake of Helen's unfortunate itinerary through her married life. With a firm hand she tells openly of whatever is necessary to give a clear idea of the situation as it is. She omits nothing relevant, and for that reason found herself censured for depicting some scenes with "a morbid love of the coarse, if not the brutal." ${ }^{8}$ But in fact, self-pity and over-sentimentalizing are alien both to the novelist and her heroine. When the latter is forced to escape from her own house to become the tenant of her old and derelict family home, Wildfell Hall, Anne Brontë, with supreme skill for suspense, like the best film directors, wins our support for the fugitive and leads us almost to the verge of clapping when she recovers her freedom: 
Early we rose, swiftly and quietly dressed, slowly and stealthily descended to the hall, where Benson stood ready with a light to open the door and fasten it after us ... What trembling joy it was when the little wicket closed behind us, as we issued from the park! Then, for one moment, I paused, to inhale one draught of that cool, bracing air, venture one look back upon the house. All was dark and still; no light glimmering in the windows ... I bade farewell for ever to that place, the scene of so much guilt and misery ... no shadow of remorse for him I left behind: there was nothing to disturb my joy except the fear of detection; and every step removed us farther from the chance of that. (394)

The Tenant of Wildfell Hall is a daring novel. The realism of the moral indictment that pervades it was a great deal in advance of her time. For Charles Kingsley, a contemporary critic of Anne Brontë's, the "whitewashed English society" should be thankful to those "who dare to show her the image of her own ugly hypocritical visage." Nevertheless, at the same time he declared the book totally unfit for girls to read. Our own contemporary Winifred Gérin (1979:7) affirms that The Tenant of Wildfell Hall "might be said to be the first manifesto for 'Women's Lib,"' adding that in presenting Helen Huntingdon's claim to an independent existence after abandoning her husband "Anne Brontë was not only shocking the social conventions of the day, but flouting the current laws of the land." Although Gérin seems to forget that already in 1798 Mary Wollstonecraft had written a still earlier feminist "manifesto," The Wrongs of Woman, she certainly has not failed to see gentle Anne's power of indictment and feminism.

The heroine of The Tenant of Wildfell Hall is very different to Anne Brontë. Helen Huntingdon is upper class, beautiful, married and a mother. Anne Brontë was none of these things. Both novelist and protagonist share, nevertheless, a deep moral outlook towards life, resolution and a great capacity for endurance. But Anne Brontë did not project her own subjectivity nor situate herself into the novel. If in Agnes Grey, despite being autobiographical, the authoress had given preference to the teaching of a truth realistically presented, not allowing any personal wishful thinking to interfere, in The Tenant of Wildfell Hall, Anne Brontë not only set herself humbly apart but, in her intention to help others, overcame her personal suffering at writing about those facts of which her brother was a tragic example. In order to tell that truth which she hoped would be useful to some, Anne went along the track of realism, where characters and setting conform a credible picture and in which, as in Agnes Grey, as in most genuine realism, humour is not absent, even if truth hurts.

To finish with, let us stress once more Anne Brontë's contribution to our knowledge and understanding of English governesses and married women in the first half of the nineteenth century, among so many other things, and the pleasure it is to encounter the sound judgement, clarity and charm of her writing. 
Notes

1. Letter to W. S. Williams on receiving his comments on The Tenant of Wildfell Hall, quoted in F. B. Pinion 182.

2. Preface to the 2nd ed. of The Tenant of Wildfell Hall (1848; Harmondsworth: Penguin, 1979), p. 29.

3. Diary entry, 31st July 1845, quoted by Winifred Gérin in her "Introduction" to The Tenant of Wildfell Hall, p. 9.

4. Preface to the 2nd ed. of The Tenant of Wildfell Hall, p. 29.

5. Ibid, p. 30.

6. It was due to Anne, already governess of the Robinson girls, that Branwell got his post as tutor to the Robinson's boy and fell passionately in love with the lady of the house. He believed himself corresponded by this married lady, and his dismissal and later disappointment were decisive for his physical and mental ruin.

7. Preface to the 2nd ed. of The Tenant of Wildfell Hall, p. 30.

8. T. J. Winnifrith, p. 120 .

\section{Works Cited}

Brontë, Anne. Agnes Grey. 1847. The Brontë Sisters: Four Novels. London: Spring Books, 1977.

Chittham, Edward. A Life of Anne Brontë. Oxford: Blackwell, 1991.

Figes, Eva. Sex and Subterfuge: Women Writers to 1850. London: Macmillan, 1982.

Gaskell, Elizabeth. The Life of Charlotte Brontë. 1857. Harmondsworth: Penguin, 1975.

Gérin, Winifred. "Introduction." The Tenant of Wildfell Hall. Harmondsworth: Penguin, 1979.

Langland, Elizabeth. Anne Brontë: The Other One. London: Macmillan, 1990.

Liddell, Robert. Twin Spirits: The Novels of Emily and Anne Brontë. London: Peter Owen, 1990.

Mackay, Angus M. The Brontës, Facts and Fiction. London, 1897.

Maurier, Daphne du. The infernal World of Branwell Brontë. London: Victor Gollancz, 1960.

Moore, George. Conversations in Ebury Street. London: Chatto and Windus, 1930.

Sambrook, Hana. Notes on The Tenant of Wildfell Hall. Harlow: Longman, 1984.

Winnifirth, T. J. The Brontës and their Background. London: Macmillan, 1977. 